\title{
A Fuggerektől a Fuggerekig? Avagy létezhet-e szuverén állampénzügyi rendszer a mi emberöltőnkben?
}

\section{Főszerkesztői beköszöntő}

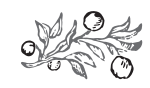

Journal of Economic Literature (JEL) kódok: B20, N01

Kulcsszavak: pénzügypolitika, államadósság, pénzügyi hatalomtechnika, Magyarország

A harmincéves háborút a történelemtudomány a 17. század világháborújának is említi, amely egyike volt Európa legpusztítóbb konfliktusainak. Ennél nagyobb rombolást később csak a napóleoni háborúk, még később pedig az első és a második világháború okozott. Bár a harmincéves háborút jobbára vallásháborúként aposztrofálják, amely a katolikusok és protestánsok ellentétére alapult, ám a háború fő törésvonalai a Német-római Birodalmon belül a megerősödésre törekvő császári hatalom és az abszolutizmussal szembeszálló választófejedelmek között húzódtak, míg az európai hegemóniáért a Habsburgok és a Bourbonok vetekedtek. A harmincéves háború hatásai között említhető, hogy a növekvő számú és kiképzettebb, jobban felszerelt zsoldosseregekre való igény kikényszerített államszervezési és pénzügyi változásokat. A harmincéves háborút lezáró 1648-as vesztfáliai béke pedig azért ívódott be a történelmi emlékezetbe, mert utat nyitott a független államok kialakulásához. A leglényegesebb hatás azonban az a felismerés volt, hogy a háborúk megvívásához, és az általuk történő hatalom és gazdasági befolyás szerzéshez stabil alapokon álló állampénzügyi rendszer szükségeltetik, vagy ha az nincs, úgy a háborút mérhetetlenül finanszírozó bankokra. Vagyis, a katonai siker már nem is annyira a katonák hősiességén, vitézségén múlik, hanem a hadsereg felszereltségének minőségén, valamint a mögötte álló államkassza forrásainak, illetve az állam által felvett hitelek bőségén.

Ám vannak a háborúk és a hatalomszerzés gyakorlatának mélyebb, s főleg korábbi öszszefüggései is a középkorból. A 15-16. században sem a pápa-, sem a császárválasztás egy, a délnémet Augsburgól felemelkedő család megkerülésével nem történhetett. Fugger Jakab (1459-1525) és Fugger Antal (1493-1560) leghíresebb tranzakciói közé tartozik az 1519. évi császárválasztás, amikor az általuk biztosított kölcsönnek köszönhetően foglalhatta el a császári trónt V. (Habsburg) Károly, kiszorítva ezzel a francia királyt. Áttételesen a reformáció 
kirobbanásához is hozzájárultak, hiszen Albert mainzi érsek a Fuggerektől felvett kölcsön törlesztésére rendelte el - pápai jóváhagyással - a búcsúcédulák árusítását, ami ellen Luther Márton 1517. október 31-én a wittenbergi vártemplom kapujára szegezett 95 tézisből álló vitaindító dokumentumával tiltakozott.

Nem tovább folytatva a Fuggerek befolyás-, és hatalomszerzésének tételes felsorolását, rendszertani megközelítésből rögzíthetjük, hogy államférfiak helyett magánvállalkozóként irányítottak, kormányoztak. Tőlük függött, mint utaltam rá, hogy egy Habsburgot vagy egy Valois-t választanak-e német-római császárnak. Általuk az állam és a korai monopolkapitalizmus egybeolvadása kiteljesedett. Ennél fogva a rendi államban, majd a korai kapitalizmusban az állam már a magángazdaságtól függött. A 15-16. században a gyarmatosítás, a kizsákmányolás, az erőforrások egyenlőtlen megoszlása is kedvezett olyan pénzügyi köröknek, mint a Fuggerek, akik átlátták a folyamatokat, és magukat a fejlődés középpontjába, sőt már rögtön a kiinduló pontjába helyezték. Igaz, a Fuggerekkel kezdődött az európai gazdaság diadalmenete, ők lettek a világ első multinacionális konszernje, és olyan gazdasági-pénzügyi szervezeti minták létrehozói, amelyek máig nem avultak el. Hasznot húztak a fejedelmek bűnös szenvedélyeiből, a tengeri hajósok felfedezéseiből, kihasználták a tudósok újításait, valamint a hívők túlvilágtól való félelmét is. Kihasználták a piac hatalmát, manipulálták az árakat, árfolyamokat, kamatokat, míg vetélytársaik csődbe nem mentek. Igaz, ezen tranzakciók nyereségeivel növelni lehetett volna a nemzetek jólétét. Ám a népvagyon jelentős részét háborúkra pazarolták az uralkodók, amelyek emelkedő költségeit a Fuggerek finanszírozták, busás kamatokért és a befolyásért. Befektetéseik pénzügyi megtérülésére, sőt hatalmi befolyásuk növelésére bizton számíthattak. Gazdasági súlyukat összegezve azt mondhatjuk: a Fuggerek a kor gazdasági életének szinte minden ágazatát uralták. A legnagyobb földbirtokosok, felvidéki bányatulajdonosok, bankárok, pénzverők és fegyvergyártók voltak, ők hitelezték a császárválasztás költségeit, a hadseregek fenntartását, szinte korlátlanul adták a kölcsöneiket, amelyek révén az államirányításban meghatározó befolyást szereztek. ${ }^{1}$

A 20-21. század legprofesszionálisabb pénzkölcsönzői az 1944-ben létrehozott két Bretton Woods-i pénzügyi óriás, a Világbank és a Nemzetközi Valutaalap. Pénzt hiteleznek fejlődésben visszamaradt, vagy a válságok következtében meggyengülő országoknak. Végső soron szüksége is van e két intézményre azon kormányoknak, amelyek nem képesek önállóan, saját erőből, olyan állami gazdasági szervezetet, szabályozó rendszert, s általuk pénzügyi kiszámíthatóságot, belső forrásfeltöltést létrehozni, amelyből az állam működése, az állampolgárok szociális biztonsága, életszínvonal igénye az elvárható módon biztosítható lenne.

De ne feledkezzünk meg a világban jelentős más pénzkölcsönzőkről, befektetőkről sem, mint például az államadósság finanszírozáson profitáló Franklin Templeton Investments-ről, vagy Warren Buffett-ről, akinek zseniális befektetései közé tartozik a Coca-Cola Company, a Gillette, a Fruit of the Loom, továbbá repülő-, bank- és biztosítótársaságok részvényeinek megszerzése. Találó meghatározás az Egyesült Államokban, hogy Warren Buffett-tel akkor is találkoztál már, ha még nem találkoztál. A légiközlekedéstől az élelmiszeriparig mindenhol vannak érdekeltségei. Sőt, még a cégei hitelminősítését végző egyik nagy nemzetközi hitelminősítő cégben is részvényes. A Forbes magazin 2008-as listáján ő volt a világ leggazdagabb embere, a mexikói Carlos Slim és a Microsoft alapító Bill Gates előtt. Hatalma, vagyona, 
befolyása azóta is meghatározó, jóllehet a 2007-2008-as nagy amerikai jelzálogpiaci összeomlásért sokan őt (is) okolták.

Igen, modern korunkban is vannak az évszázados lemaradásból, vagy éppen vezetőik alkalmatlansága okán is olyan országok, amelyek rászorulnak a Világbank, vagy a Templeton kölcsöneire és Warren Buffett multinaconális konglomerátumának, a Berkshire Hathaway² világot behálózó tőkepiaci „kisegítéseire”, bár ezek már nem annyira nyers befolyásszerzések, mint Fuggerek idejében, de az adós, a kötelezett helyzete alárendelté válik. Még akkor is, ha a gazdasági erőt már nem a hitelből felszerelt hadseregekkel, csatamezőkön aratott győzelmekkel alapozza meg egy adott ország, hanem gazdasági erejével, s rajta keresztül belső társadalmi- és nemzetközi érdekérvényesítő képességével. De ha nincs belső, „önszervezett” ereje egy kormánynak a gazdasági stabilitás fenntartásához, úgy, ha hitelért folyamodik, bizony számolnia kell a hatalmának megosztásával. Mert bizony a hitelezők - az évszázados gyakorlat szerint - részt kérnek.

11 év polgári kormányzás után napjaink dilemmája, hogy állampénzügyi stabilitásunkat, és főleg annak saját erőből történő fenntartását meddig, s hogyan tudjuk megőrizni. Az erre vonatkozó reményeink megalapozottak, hiszen a Trianon utáni száz év legsikeresebb tíz évét tudhatjuk magunk mögött, amelyet még a Covid-19 okozta járványválság sem tudott kikezdeni. És nagyot léptünk előre a gazdasági felzárkózásban is. A 9-11. században végbement honfoglalás, majd államalapítás eleve adott egy letelepedési késettséget, államalapítási „időeltolódást”’, s gazdasági „visszavetettséget”, melynek okán az észak-itáliai városállamok és a délnémet városok körül generált nemzetközi kereskedelembe jobbára csak a lábon hajtott szarvasmarhával, mint nem túl magas hozzáadott értékű áruval tudtunk becsatlakozni. És az Amerika felfedezésével járó globalizációból, új világrendből, gazdagodásból pedig lényegében ki is maradtunk. A török háborúk fejlődést késleltető hatásai után az Osztrák-Magyar Monarchia dualista államszervezetében „találtunk magunkra”, ám az I. és II. világháború veszteségei, s annak következményei gazdaságilag ugyancsak visszavetettek bennünket.

Ám 2010-től szisztematikusan felépítettük magunkat, csökkent az államadósság, nőtt a gazdaság teljesítőképessége, a társadalom anyagi jóléte, s mindezt nem hitelből értük el. Sőt a világbankos és nemzetközi valutaalapos hiteleket visszafizettük, gazdaságpolitikánkba történő beleszólásukat elhárítottuk.

A kérdés, illetve a feladat most az, hogy a rendszerváltás elhibázott gazdaságpolitikája, majd a 2007-2008-as bank- és adósságválság konszolidálása után, de már egy újabb, Covid-19 hullámokkal járó járványválság új világrendet teremtő rendszerébe, a termelés, a szolgáltató szektor és a bankpiac új tektonikus lemezeire (fejlődési irányaira) hogyan tudunk felkapaszkodni. Mennyire tudjuk megoldani a termelési szerkezetünk korszerűsítését, államgazdaságunk működésének fegyelmezettségét, a vállalati hatékonyság növelését, a termékeinkben lévő hozzáadott érték arányának növelését, a bérek, és az életszínvonal felzárkóztatását, vagyis (illetve általuk) az állam és a társadalom saját szervezésből, belső erőforrások előteremtéséből és felhasználásából történő biztosítását, kiszámítható, s főleg nem külső hitelekből történő finanszírozását. Nehogy a kései Fuggerek által hitelezettek, vagy a Nemzetközi Valutaalap adósai közé keveredjünk, s újra az IMF Alapokmány 4. cikkelye szerinti gazdaságpolitikai „,konzultációra" kényszerüljünk, vagyis a költségvetési jogunk, költségvetés alkotásunk függetlenségének 
csorbulását szenvedjük el. Történelmi kérdés jó egy évtized után, hogy mi az esélyünk, és ha előre akarunk lépni, úgy milyen pénzügyi politikát alkalmazzunk.

Ehhez az eligazodáshoz ad iránytűt, sok jó tanácsot a Polgári Szemle, amely 17. évfolyamának dolgozatai, így a 4-6. magyar lapszámé is, erre keresik a választ.

Érdemes Polgári Szemlét olvasni!

Kelt: Budapesten, a 2021. év Adventjén

Prof. dr. Lentner Csaba egyetemi tanár

a Polgári Szemle főszerkesztője

\section{JEGYZETEK}

1 Forrás: Gunter Ogger (1978): Die Fugger: Bankiers für kaiser und könige. Droemersche Verlagsanstalt Th. Knaur Nachf. München/Zürich. Köszönettel tartozom Dr. Janza Frigyes tábornok úrnak, ny. r. vezérőrnagynak, hogy a kormányzás, irányítás és a pénzügyek összefüggésére a figyelmemet jó egy évtizede kitartóan fókuszálja, irányítja, s a hivatkozott könyvet is figyelmembe ajánlotta.

2 A cég tulajdonosa a GEICO, a Duracell, a Dairy Queen, a BNSF, a Lubrizol, a Fruit of the Loom, a Helzberg Diamons, a Lond \& Foster, a FlightSafety International, a Pampered Chef, a Forest River és a NetJets-nek. Ezek mellett meghatározó részesedést birtokol a Pilot Flying, a Kraft Heinz, az American Express, a Coca-Cola, a Bankf of America és Apple cégekben. 2016 óta a cég nagy számú részvényeket vásárolt vezetỏ amerikai légitársaságokban, bár ezeket 2020 elején eladta.

3 Államalapításunk több mint fél évezreddel később történik, miután a fejlett adminisztrációval, közigazgatással, hadsereggel rendelkező Nyugat-Római Birodalom felbomlott, s letelepedésünk idején tőlünk nyugatra „zárt”, fejlett államalakulatok múködtek már. 


\section{From the Fuggers to the Fuggers? Can a sovereign public finance system exist in our generation?}

\section{Editor-in-Chief's Welcome}

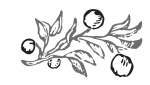

Journal of Economic Literature (JEL) codes: B20, N01

Keywords: monetary policy, government debt, monetary power techniques, Hungary

The Thirty Years' War is also referred to as the world war of the 17 th century by historical science; it was one of the most devastating conflicts in Europe. Larger destruction was later caused only by the Napoleonic Wars, and even later by the First and Second World Wars. Although the Thirty Years' War is usually referred to as a war of religion based on the unrest between Catholics and Protestants, the main fault lines ran within the Holy Roman Empire between imperial power, striving for strengthening, and the prince-electors challenging absolutism, while the Habsburgs and the Bourbons were each other's rivals for European hegemony. The effects of the Thirty Years' War include changes in state organisation and finance, which were brought about by the need for larger, better trained and better equipped armies of mercenaries. The 1648 Peace of Westphalia, ending the Thirty Years' War, has been kept in historical memory as it gave way to the emergence of sovereign states. However, the most significant effect was the recognition of the fact that fighting wars and gaining power and economic influence required a robust public finance system, or, if it did not exist, banks which financed the war infinitely. That is, military success did not depend so much on the heroism and valour of soldiers but rather on the quality of the equipment of the army and the abundance of the resources in the state's coffers backing them or the loans taken out by the state.

However, there are deeper, and in particular, earlier connections between wars and seizing power from the Middle Ages. In the 15th and 16th centuries, no popes or emperors could be elected by bypassing a family rising from Augsburg, southern Germany. The most famous transactions of Jakob Fugger (1459-1525) and Anton Fugger (1493-1560) include the election of the pope in 1519, when the throne of the emperor was taken by Charles $\mathrm{V}$ (of Habsburg) over the French king as a result of a loan provided by them. Indirectly, they also 
contributed to the breakout of the reformation, since Albert, Archbishop of Mainz, ordered - with the permission from the pope - the sale of indulgences to repay the loan taken out from the Fuggers, against which Martin Luther protested in his debate-provoking document comprising his Ninety-five Theses, nailed to the door of All Saints' Church in Wittenberg on 31st October, 1517.

Without a further account of how the Fuggers gained influence and power, from a taxonomical approach we can conclude that in lieu of statesmen, they exercised control and governed as private entrepreneurs. As I have already mentioned, it depended on them whether a Habsburg or a Valois was elected as the Holy Roman Emperor. The merging of the state and early monopoly capitalism was completed by them. Therefore, in feudal states and then in early capitalism, the state depended on the private economy. In the 15th and 16th centuries, colonialism, exploitation, and an unequal distribution of resources were favourable for such financial circles as the Fuggers, who had complete understanding of the processes, and placed themselves in the centre, or even in the origin of development and progress immediately. Truth be told, the European economy set out on its journey to triumph with the Fuggers, they became the world's first international concern, and the creators of such models of economic and financial organisations which have not become obsolete to date. They profited from the sinful passions of princes, the discoveries of seafarers, they took advantage of the inventions of scientists as well as of the believers' fear of the afterlife. They made use of market power, manipulated prices, exchange and interest rates until their rivals went bankrupt. It is also true that the profit from these transactions could have increased the prosperity of nations. However, monarchs squandered a significant share of collective property on wars, the increasing costs of which were funded by the Fuggers, in exchange for massive interests and influence. They could confidently expect the financial return on their investments and also the increase of their leverage. Summing up their economic weight, we can say that they ruled over almost all branches of the economic life of their time. They were the greatest landowners, mine owners in Upper Hungary, bankers, minters and weapon manufacturers, since they provided loans to cover the costs of electing the emperor and the maintenance of armies, and gave loans practically without any limits, through which they gained major influence in the governance of the state. ${ }^{1}$

The most professional lenders of the 20th and 21 st centuries are the two financial giants founded in Bretton Woods in 1944: the World Bank and the International Monetary Fund. They lend money to underdeveloped or crisis-stricken and therefore weakening countries. After all, these two institutions are needed by governments which are unable to create independently, from their own resources such a state economic organisation and a regulatory system through which financial predictability is achieved and the liabilities are made good internally to ensure the operation of the state, the social security of citizens and fulfil their need for a higher standard of living as expected.

But let us not forget about other significant lenders and investors of the world, either, such as Franklin Templeton Investments, profiting from funding government debt, or Warren Buffett, whose brilliant investments include the Coca-Cola Company, Gillette, Fruit of the Loom, as well as the acquisition of airlines, banks and insurance companies. In the USA, 
there is a very apt definition, saying 'You have already met Warren Buffett even if you have not met him yet'. He has interests everywhere, from aviation to the food industry. He is even a shareholder of a large international credit rating firm conducting the credit rating of his own companies. In 2008, he was the world's richest person on the annual listing of Forbes magazine, soaring past Carlos Slim from Mexico and Bill Gates, the founder of Microsoft. His power, wealth and influence have been decisive ever since, although he (among others) was blamed by many for the great collapse of the US subprime mortgage market in 2007 and 2008.

Yes, in our modern era, there are countries which, due to their century-long backlog or the incompetence of their leaders, badly need the loans of the World Bank or Templeton, as well as the worldwide network of stock market "assistance" by Warren Buffett's multinational conglomerate, Berkshire Hathaway ${ }^{2}$, although these are not so harsh ways of gaining influence as they were in the days of the Fuggers; still, the debtor, and the obligor has a subordinated status. This is so, even though the economic might of countries is no longer based on victories won in battlefields by armies equipped from loans, but their economic strength, and through that, their ability to assert their internal social and international interests. But if a country lacks internal, "self-organised" strength to maintain economic stability and resorts to a loan, it should take the division of its power into account as lenders, - according to century-long practice - ask for their share.

After 11 years of conservative governance, today there is a dilemma about how long and in what way the stability of our public finances, and in particular, its maintenance based on our own resources can be preserved. Our hopes about it are grounded, as these have been the most successful ten years of the century elapsed since the Treaty of Trianon, and this success has remained unmarred despite the pandemic crisis caused by the COVID-19. We have made great progress in economic convergence as well. The Hungarian conquest of the Carpathian Basin at the turn of the 9th and 10th centuries and the foundation of the Hungarian state caused a delay in settling down, a "jetlag"3" in founding our state, and an economic "backwardness", as a result of which "cattle driven to markets", representing relatively low added value, was our only contribution to international trade generated around the city states in northern Italy and the cities in southern Germany. We were practically left out of the globalisation, the new world order and the enrichment entailed by the discovery of America. After the adverse effects of the Ottoman-Hungarian Wars on our development, we "reinvented ourselves" in the dual state organisation of the Austro-Hungarian Monarchy, but the losses suffered during World War I and II and their aftermath also set our economy back..

However, we have systematically been building ourselves since 2010, government debt has decreased, the productive capacity of the economy and the material wealth of the society have increased, and all these have been achieved without loans. We even have paid back the loans from the World Bank and the International Monetary Fund thus, they no longer have a voice in our economic policy.

The question and the task now is how we can climb up the new tectonic plates (development trends) of production, the service sector and the banking market after the failed economic policy of the regime change and the consolidation of the banking and debt crisis in 2007 
and 2008, now in a newer system, stricken by a pandemic crisis and the attendant waves of the COVID-19, and creating a new world order. How effectively can we manage the modernisation of our production structure, the discipline of the operation of our state economy, the enhancement of corporate efficiency, the increase of the proportion of added value in our products, the convergence of wages and the standard of living, that is (and by them), how effectively can we ensure the state and the society through self-effort, by creating and using internal resources, and their predictable financing without external loans? We should avoid being a debtor of modern-day Fuggers or the International Monetary Fund, being forced to have a consultation on our economic policy, pursuant to Article IV of the IMF Articles of Agreement, that is, an impairment of our budgetary rights, of the autonomy to create our own budget. After a decade, it is a historical question as to what our chances are, and what monetary policy should be applied if we want to advance.

Polgári Szemle provides a compass and a lot of good advice to navigate this landscape, and the papers of Volume 17, including Hungarian issues No. 4-6, are seeking an answer to this question.

It is worth reading the Polgári Szemle!

Budapest, Advent of 2021

\author{
Dr. Csaba Lentner, university professor \\ Editor-in-chief of Polgári Szemle
}

\title{
Notes
}

1 Source: Ogger, Gunter (1978). Die Fugger: Bankiers für kaiser und könige. Droemersche Verlagsanstalt Th. Knaur Nachf. München/Zürich. I should thank General Dr. Frigyes Janza, ret. pol. major general, for focussing my attention on the connections between governance, control and finances for more than a decade now, and for recommending me the book referred to above.

2 The company owns GEICO, Duracell, Dairy Queen, BNSF, Lubrizol, Fruit of the Loom, Helzberg Diamons, Lond \& Foster, FlightSafety International, Pampered Chef, Forest River and NetJets. In addition, it has a considerable share in Pilot Flying, Kraft Heinz, American Express, Coca-Cola, Bank of America and Apple. From 2016, the company also purchased a high number of shares in leading American airlines, although these were sold at the beginning of 2020 .

3 Our State was founded more than half a millennium later, after the Western Roman Empire with its advanced administration, public administration and military disintegrated. At the time of our establishment developed state "formations" were closed to the west of us. 